\title{
Dynamics of Healer-Patient Confidentiality in Early Modern Witch Trials
}

\author{
Natacha Klein Käfer
}

\section{1 \\ Confidentiality from Below}

Can we talk about healer-patient confidentiality in the early modern period? The legal notion of confidentiality is very recent. In Imperial Germany, for instance, medical confidentiality only became a legal requirement for health professionals in $1871 .^{1}$ Since the Hippocratic Oath, however, patient information has been considered private, and its protecting has been part of the medical code of conduct. The oath postulates:

And whatsoever I shall see or hear in the course of my profession, as well as outside my profession in my intercourse with men, if it be what should not be published abroad, I will never divulge, holding such things to be holy secrets. Now if I carry out this oath, and break it not, may I gain for ever reputation among all men for my life and for my art; but if I transgress it and forswear myself, may the opposite befall me. ${ }^{2}$

Different historical periods have informed the parameters of medical confidentiality as we know it today, ${ }^{3}$ but the issue of not wanting compromising information to become widely available had existed long before the laws that formalise this kind of privacy. Health practitioners of the past had to use their own discretion when they acquired sensitive information. No legal standard

1 Maehle A.-H., "Protecting Patient Privacy or Serving Public Interests? Challenges to Medical Confidentiality in Imperial Germany", Social History of Medicine 16.3 (2003) 282-401, here 383 .

2 From the Loeb Classical Library's translation of the Hippocratic Oath at https://www -loebclassics-com.ep.fjernadgang.kb.dk/view/hippocrates_cos-oath/1923/pb_LCL147.299 .xml, accessed on 30 July 2020.

3 Ferguson A., "The Lasting Legacy of a Bigamous Duchess: The Benchmark Precedent for Medical Confidentiality", Social History of Medicine 19.1 (2006) 37-53, here 37. 
stipulated how to deal with private information: ${ }^{4}$ confidentiality was a temporary bond created or dissolved on a case-by-case basis. To begin to understand the dynamics of such bonds of confidentiality, we need, first, to identify the relevant sources. These include but are not limited to doctors' correspondences, medical treatises, and personal notes. ${ }^{5}$ As a point of departure, these sources can only inform us about specific kinds of bonds: they document how members of the upper echelons of society consulted educated doctors. Most of the population, however, would not be able to afford such treatment and would seek access to alternative modes of healthcare. ${ }^{6}$

The less-privileged strata of society depended mostly on local healers to deal with health issues. These members of local communities were practitioners who could alleviate everyday problems, manipulating natural as well as supernatural events in the daily lives of the common folk. Such practitioners usually operated locally, and in the early modern period, it was common for a village to have one or more of these practitioners. They applied a variety of techniques to help their fellow villagers, including applied herbal knowledge, the use of verbal charms, and forms of divination. Some of them specialised in certain functions, such as love charms or witch detection. These specialisations could be rumoured outside of villages, and people from a wider area would commission practitioners on account of particular skills. Due to the nature of the service provided, these practitioners could be privy to their clientele's most private information. Just as doctors had the Hippocratic Oath, local healers had to develop their own bonds of secrecy with their clientele since this close relationship would demand a significant level of trust. These bonds benefitted both sides as authorities did not sanction all of the local healers' practices, so seeking their help could be perceived as superstitious at best and criminal at worst. As such, a certain level of confidentiality protected both the healers and their clientele. ${ }^{7}$

4 Private information in this case refers to more than personal health details, but also information that the individual disclosed to the practitioner regarding aspects of their life that were meant to remain within the confines of the healer-patient communication and that could affect the person in case it reached public ears.

5 Michael Stolberg utilised a sixteenth-century physician's private notebooks to explore doctor-patient relationships, see Stolberg M., "'You Have No Good Blood in Your Body'. Oral Communication in Sixteenth-Century Physicians' Medical Practice", Medical History 59.1 (2015) 63-82.

6 For a more nuanced overview, see Weindling P. (ed.), Healthcare in Private and Public from the Early Modern Period to 2000 (New York: 2015).

7 For an overview of these healers' practices and their complex interactions with authorities and population, see De Blécourt W., "Witch Doctors, Soothsayers and Priests. On Cunning Folk in European Historiography and Tradition", Social History 19.3 (1994) 285-303. 
There are few surviving records of popular experiences with these local healers. Moreover, most of these healers transmitted their knowledge predominantly through oral traditions, which are hard to reconstruct. ${ }^{8}$ In order to mitigate this dearth, historians rely upon indirect sources such as witch trial records. ${ }^{9}$ By reading such official documents against the grain, ${ }^{10}$ we are able to grasp how everyday people shared knowledge, dealt with their reality, and engaged with one another. Witch trials, especially those involving local healers, can be a fruitful source for investigating the bonds between popular healers and their patients. ${ }^{11}$ Given their unique insight into private lives, the testimonies of healers are a lens through which we can observe some of the kinds of privacy that existed among villagers.

As historical sources, such testimonies are not objective accounts: the use of threats and torture during interrogations primed the type of answers that could be given, and the very nature of the records distorts our access to the past. ${ }^{12}$ Despite the many layers of interference, close analysis of these records enables us to extract useful pieces of information from these highly contentious sources. In his famous essay "The Inquisitor as Anthropologist", Carlo Ginzburg stresses the historical potential of witch trials, demonstrating that a dialogic reading of the interactions between inquisitor and accused might provide new insights into popular beliefs. ${ }^{13}$ By contrasting the expectations of the interrogators with how people attempted to answer their questions, historians can get a glimpse of the systems of thought that were at play.

8 Orality was key in the transmission of healing knowledge not only among these local healers, but also among learned doctors and between lay and professional practitioners, as shown by Stolberg M. "Learning from the Common Folks. Academic Physicians and Medical Lay Culture in the Sixteenth Century", Social History of Medicine 27.4 (2014) 649-667.

9 The importance of using witch trials and the problems that these sources entail have been explored by De Blécourt, "Witch Doctors, Soothsayers and Priests".

10 Ginzburg C., History, Rhetoric, and Proof (Hanover - London: 1999) 24.

11 Although this view was often rehearsed in the scholarly literature of the 196os, 1970s, and $198 \mathrm{os}$, local healers were not the main target of witch trials. Accusations of witchcraft were tied to disruptions in the social dynamics of the village - disputes, epidemics, property conflicts, or general mistrust among neighbours. The objective of these trials was not to control or to eliminate local practitioners, see Rummel W., "Weise' Frauen und 'weise' Männer im Kampf gegen Hexerei: Die Widerlegung einer modernen Fabel", in Dipper C. Klinkhammer L. - Nutzenadel A. (eds.), Europäische Sozialgeschichte. Festschrift für Wolfgang Schieder (Berlin: 200o) 353-375; Harley D., "Historians as Demonologists: The Myth of the Midwife-witch", The Social History of Medicine 3.1 (1990) 1-26.

12 See also Laflamme's contribution to this volume.

13 Ginzburg C., "The Inquisitor as Anthropologist", in Ginzburg C., Clues, Myths, and the Historical Method (Baltimore, MD: 1992) 141-148. 
In the following, I show how close reading allows us to identify popular systems of confidentiality. These systems are malleable, based on cultural specificities, and dependent upon local social dynamics. To reinforce this dimension of fluidity in how people created and transformed social bonds, I will use the term modes of confidentiality. These modes of confidentiality are adaptable social agreements that loosely establish who can be aware of what in a given situation. As we do today, people in the early modern period selected what kind of information they shared, tailored their narratives according to each group they had to interact with, and used pieces of other people's private information when needed. Such interactive networks led to the creation of implicit trust agreements: breaching such bonds had consequences. Thus, the following examination details how common people dealt with the circulation of private information, highlighting when and why different levels of confidentiality were required.

I will use three contrasting cases of witchcraft accusations as sources: the first is the emblematic fifteenth-century trial of the healer and brewer of love potions Matteuccia di Francesco from Ripabianca, district of Todi (Italy); the second is the seventeenth-century trial of the midwife Anna Starck, accused of infanticide and providing abortions by the court of Mainz (Germany); and the third is the seventeenth-century case of Clara Hoffmann who was denounced as a witch in the Electorate of Trier (also Germany) with the help of a local practitioner's testimony. These three cases have been chosen in view of the uniqueness of the circumstances surrounding each trial and the singularity of the information presented during the proceedings. Matteuccia's is considered a seminal case in the European persecution involving a healer, and, as such, serves as a stepping stone to observe the later developments in the seventeenth century. This juxtaposition highlights the different modes of confidentiality at play, showing how the cases present contrasting dynamics of protection or revelation of information.

\section{$2 \quad$ Modes of Confidentiality}

\subsection{Revealing Daily Lives}

One of the earliest witch trials in Europe, possibly the first record of the idea that witches perform night flights, ${ }^{14}$ focuses on a local healer: Matteuccia di Francesco (ca. 1388-1428), who, in 1428, was accused of being 'feminam male

14 Conti F., "Notes on the Nature of Beliefs in Witchcraft: Folklore and Classical Culture in Fifteenth Century Mendicant Traditions", Religions 10.10 (2019) 576. 
conditionis vite et fame, publicam incantatricem, facturariam et maliariam et stregam' ('a woman of a bad life and reputation, public enchantress, sorceress, evil spell caster, and witch'). ${ }^{15}$ The records of her trial include a detailed account of the charms she used, which consisted primarily of healing prayers ${ }^{16}$ and love spells. ${ }^{17}$ The latter kind seems to have been her speciality. The main clientele for the love spells, according to the record, were women who were in abusive relationships, or that had been abandoned by their partners. On top of providing these services, Matteuccia was also accused of flying in through people's windows and sucking the life out of children.

When read against the grain, Metteuccia's trial provides subtle hints of how private information could be used in trial. These hints, however, have to be extracted from the very structured narrative of the record. The record strives for uniformity: throughout the trial, all of Matteuccia's actions are attributed to the inspirations of demonic spirits, regardless if she is described as healing or sucking the life out of children. This is done by the repetition of the descriptor 'mala malis addendo, diabolico spiritu instigata' ('adding evil to evil, inspired by the demonic spirit') affixed to most of the paragraphs detailing Matteuccia's activities, making sure that there is no doubt that all her actions should be understood within this frame. The record acknowledges how she 'incantauit corporis, ac capitis et aliorum membrorum patientes [...] pro supradictis et aliis infirmitatibus' ('enchanted the body, head, or other limbs of patients [...] for the abovementioned and other diseases'), but regardless if the removal of illnesses was assumed to be true, it remained as evidence of her guilt as a witch. Practices that could be considered helpful by women in violent relationships were framed as undermining the sacrament of marriage. ${ }^{18}$ Even when her healing prayers were directed to Christ and the Virgin Mary, they still appear under the 'diabolico spiritu instigata', just as her night flights. ${ }^{19}$

This mix of folk healing and popular rituals with demonic pacts and night flights in Matteuccia's trial is not necessarily surprising, especially considering that her conviction happened only two years after the visit of Bernardino of Siena - the renowned Franciscan friar who blended elements of folklore into

15 Processo alla strega Matteuccia di Francesco, 20 marzo 1428, trans. D. Mammoli (Todi: 1969) 18-19. In the original document (Archivio Comunale di Todi, Sala VI, vetrina processi, n. 20) fol. $21 \mathrm{v}$.

16 Ibidem, 14-15. Original fol. 21v.

17 Ibidem, 20-21, 24-25. Original fol. 22r.

18 Ibidem, 28-29. Original fol. 22v.

19 Ibidem, 16-17. Original fol. 21v. 
his depictions of witchcraft. ${ }^{20}$ However, the way Matteuccia's healing practices are weaved into the trial can be indicative of how evidence and information reached court. The record states that her case was brought to trial due to the complaints of reputable men. ${ }^{21}$ Following the accusation, the court proceeded with interrogations and collection of evidence. The record does not specify where the disclosed information came from, so we can only speculate what kind of detail was provided by Matteuccia herself during her interrogation. Nevertheless, this speculation can be informed by the kind of information that was revealed - especially considering the consequences for the people involved if such stories became public knowledge.

As people visited Matteuccia to request her help, private information became a necessary part of the exchange. She would not have been able to help her patients without the details of what was happening to them that required her help, and, as such, intimate details of their lives became another form of knowledge Matteuccia had under her belt. For instance, it was disclosed in the trial that a woman from the castle of Prodo in the district of Orvieto came to Matteuccia with the complaint that the local priest, with whom she was romantically involved, stopped caring for her and would beat her on a daily basis. She asked for a remedy to bring back his love and Matteuccia provided her with a spell using a wax figure. As a result, the priest soon after declared his love for the woman again. ${ }^{22}$ Although relationships between priests and their female servants were not uncommon, ${ }^{23}$ bringing attention to the priest's involvement with the woman - as well as the woman's willingness to request a spell to keep the priest's favour - could create trouble not only for the couple but also for the Church as a whole.

Many other women are described in the trial as seeking Matteuccia's help with similar issues. A certain Catarina from the district of Orvieto also came to her to find a solution for the constant beating she suffered at the hands of her husband. ${ }^{24}$ Another woman approached Matteuccia with the complaint that her husband treated her badly. This client was given an egg and a herb called 'cavallina' (probably horsetail leaves) that, when cooked and served to the husband, would ensure that he, within a couple of days, became infatuated with her. A woman named Giovanna came from Perugia to request Matteuccia's

$20 \quad$ Bailey M.D., "Nocturnal Journeys and Ritual Dances in Bernardino of Siena", Magic, Ritual, and Witchcraft 8.1 (2013) 4-17.

21 Mammoli, Processo 14-16. Original fol. 21v. The exact expression used was 'veredicis et fide dignis hominibus et personis'.

22 Ibidem, 22-23. Original fol. 22r.

23 See Cossar R., Clerical Households in Late Medieval Italy (Cambridge: 2017).

24 Mammoli, Processo 23-24. Original fol. 22r. 
help, since her husband mistreated her and had left her for another woman. ${ }^{25}$ In each of these cases, the women had to place a certain level of trust in Matteuccia. The only thing guaranteeing that Matteuccia would not reveal their domestic condition to the public was this implicit bond of confidentiality between the afflicted and the helper. However, under trial, this bond could succumb to the external pressures.

It would have been difficult for the accusers to collect details about Matteuccia's patients if we consider that many of her clients would have preferred that the reason they became involved with her remained private. In fact, their names, locations, and relationships added little to the persecutors' claims when they already had damning charges of Matteuccia's nocturnal flights and life-sucking powers. It is more probable that these private details were offered by Matteuccia herself during the trial and that they subsequently became entangled with the fabricated narrative of her evil-doings. ${ }^{26}$ This information might have been extracted via careful interrogation, or through the use of threats and torture, but it could also have been volunteered by Matteuccia to argue that her practices were a helpful contribution to the community. ${ }^{27}$ In either case, the confidential bonds established between healer and patient could not be maintained in this context. The case of Matteuccia demonstrates that within the constraining circumstances of the trial, trust bonds could be broken, secret information revealed, and the knowledge of 'private' circumstances turned into 'evidence'.

\subsection{Revealing Practices}

Across the sixteenth and seventeenth centuries, healers continued to be brought to trial under accusations of witchcraft. ${ }^{28}$ The turmoil following the Reformation and subsequent wars afflicting most of Europe had an impact on

25 Ibidem, 26-27. Original fol. 22v.

26 For details of the inquisitor's fabrications and the cultural information revealed by Matteuccia, see Montesano M., Classical Culture and Witchcraft in Medieval and Renaissance Italy (Cham: 2018) 173-180.

27 This is especially the case in the references to the use of healing prayers to help many patients that were in pain, as in fol. 21v. Nevertheless, some of the charms prescribed by her did not follow Christian dogma, referring more to popular beliefs in the conjuration of helpful spirits, as in fol. 22v.

28 See Behringer W., Witchcraft Persecutions in Bavaria: Popular Magic, Religious Zealotry and Reason of State in Early Modern Europe (Cambridge - New York: 2003); Briggs R., The Witches of Lorraine (Oxford: 2007); Lippi D. - Weber D., "Witchcraft, Medicine and Society in Early Modern Europe", Archives of the History and Philosophy of Medicine 75.1 (2012) 68-73; Whaley L., Women and the Practice of Medical Care in Early Modern Europe, 1400-1800 (London: 2011). 
the theological and legal ideas of witchcraft, and many legal codes had paragraphs dealing specifically with local healers. ${ }^{29}$ Most cases of accusations of witchcraft against healers in German-speaking territories took place in the seventeenth century, both in Catholic and Protestant regions. ${ }^{30}$ By the end of the century, the focus had changed significantly from accusations centred around pacts with the devil to trials based on the use of dangerous 'superstitious' forms of healing and dealing with daily problems. Nevertheless, the shift was a gradual one, and traditional views of the witches' sabbath eventually became entangled with healing practices. ${ }^{31}$

An illustrative example of such entanglement is the case of the midwife Anna Starck (?-1627). She was accused of witchcraft and infanticide in the Electorate of Mainz, a Catholic state of the Holy Roman Empire. She was executed on the first day of October $1627 .{ }^{32}$ Anna was a former bell-ringer and the widow of a baker. During her trial, she confessed to having provided the means of abortion (savin juniper and hazel) to a certain Michel Winder's daughter, who came from the neighbouring village of Umstadt to deal with her pregnancy. Given that Winder's daughter was pregnant out of wedlock, it was safest for her to seek an abortion outside her own village in order to keep this information private. This accusation of aiding an abortion was already incriminatory towards Anna since providing abortions was a capital offense. ${ }^{33}$ However, the description of the trial provides much greater detail of how Anna learned midwifery as proof of the evil intentions behind her practice. The record states that Anna claimed that the process of learning to be a midwife included a baptism by the devil, who appeared as a man dressed in black with hooves for feet, and that she would engage in nocturnal dances with other members of her community,

29 For instance, Kursächsische Konstitutionen of 1572 stipulated that those who were accused of using healing prayers or helpful divination should be imprisoned and receive Bible lessons, while other practitioners should receive capital punishment. See Frider P., Consultationum Saxonicarum (Frankfurt, Nicolai Hoffmann: 1616) 6o3.

30 Authors like Brian Pavlac point to the overall spike of witch trials during the Thirty Years War, which possibly played an important role in the number of healers found in the records. See Pavlac B., Witch Hunts in the Western World: Persecution and Punishment from the Inquisition through the Salem Trials (Westport, CO - London: 2009) 66.

31 Erik Midelfort perceived this shift in witch-hunting from the regular 'witch crimes' to the uses of blessings and fortune-telling in the seventeenth century as part of his theory of how the witch hunts came to an end. See Midelfort E., Witch Hunting in Southwestern Germany (1562-1684) (Stanford, CA: 1972) 82.

32 The trial does not specify whether Anna Starck was a resident of the city of Mainz or whether she was from one of the nearby villages and was only brought to trial in Mainz.

33 Lewis M.B., Infanticide and Abortion in Early Modern Germany (London - New York: 2016) 24 . 
at least one of whom was also a midwife. These descriptions adhere to the standard image of a witches' sabbath, ${ }^{34}$ and according to the trial records, this information was given by her without the use of torture: 'sagt guttlichen Vnd ohne tortur' ('plainly stated and without torture'). ${ }^{35}$ In this narrative, Anna's healing practices are tied to the devil from the very beginning.

Usually, when a midwife was brought to trial, every child that she had been in touch with, and who eventually ended up dying, became evidence of her evil doings. The record describes how Anna would visit people's houses to deal with illnesses or to check on infants, but the children ended up perishing. Anna then allegedly confesses to having killed children, women, and cattle using her Zauberschmir (witches' ointment). ${ }^{36} \mathrm{But}$, at the same time, she admits to using a prayer for childbirth, which includes traditional patterns of folk healing: an apocryphal story of Christ and Mary walking through a city, finding the disease the prayer is for (in this case, a woman in labour), and then relieving the person from their suffering. ${ }^{37}$ God or the Holy Trinity were also called to intervene. ${ }^{38}$

This prayer seems to contradict the belief that one must renounce God in order to become a midwife as described by Anna. Adding to this inconsistency, Anna claimed to have used charms to protect the cattle from witches, despite confessing to having bewitched livestock herself. ${ }^{39}$ She also attended Mass regularly and took her sacraments as expected. ${ }^{40}$ The idiosyncrasy of these descriptions demonstrates how conflicting views of permissible and condemnable practices became entangled with traditional ideas of witchcraft. While Anna might have revealed her use of charms as something that she considered an essential part of her work as a Christian healer, her prosecutors used

34 On the cultural markers of the witches' sabbath, see Ginzburg C., Ecstasies: Deciphering the Witches' Sabbath (New York: 1991); Hutton R., "The Wild Hunt and the Witches' Sabbath", Folklore 125.2 (2014) 161-178; Roper L., "Witchcraft and the Western Imagination", Transactions of the Royal Historical Society 16 (2006) 117-141.

35 Stadtarchiv Mainz, 28/291, Lage 83, fol. 45r. Transcribed as part of the Hexenprozesse in Kurmainz project. This kind of disclaimer appears in witch trials even when actions which today would fit the definition of torture are performed: the definition of torture in these records concerns very specific forms of physical punishment.

36 Stadtarchiv Mainz, 28/291, Lage 83, fol. 5or.

37 Several examples can be found in Holzmann V., "Ich beswer dich wurm und wyrmin ..." Formen und Typen altdeutscher Zaubersprüche und Segen (Bern - Berlin - New York: 2001); Schulz M., Beschwörungen im Mittelalter: Einführung und Überblick (Heidelberg: 2003); Ernst W., Beschwörungen und Segen: angewandte Psychotherapie im Mittelalter (Cologne: 2011).

$3^{8}$ Stadtarchiv Mainz, 28/291, Lage 83, fols. 51v. $-5^{2 r}$.

39 Ibidem, fol. $5^{2 r}$.

40 Ibidem, fol. $5^{2 v}$. 
it as evidence of her diabolism, similar to the descriptions of witch salves and encounters with the man in dark clothes with hooved feet.

Anna Starck's testimonies require attention to detail. They were guided by means of rhetoric or threat of torture to cohere with the inquisitor's purposes and expectations. However, even within those guided answers, we can still find innocuous pieces of information that reveal details about people's knowledge and experiences. This kind of interrogation can inadvertently provide historians with a fleeting but valuable insight into how local midwives operated: providing both physical and spiritual assistance during childbirth, using prayers and rituals to alleviate the mother's pain and to protect the baby, supplying means of contraception and abortion, and offering services even to older children by paying house visits in cases of sickness. Most importantly for our context, it shows how midwives had a privileged position to access people's private information. Unfortunately, this brief glimpse does not extend so far as to let us know what happened to Michel Winder's daughter after the secret of her abortion was exposed in court. The only other 'client' whom Anna implicated during the trial was a certain Fauhtin's daughter. Anna described how she had helped the mother press the baby's soft spot at birth to kill it. ${ }^{41}$ Although Anna specified that in the case of Winder's daughter, the decision was made 'damitt sie nicht zu schanden wurde' ('so that she would not be brought to shame') because of the unsanctioned pregnancy, no such details were given for Fauhtin's daughter. Apart from these two cases, Anna kept information about other possible abortions or people seeking contraception to herself. The only other names mentioned were of those whose children had perished, none of whom were implicated in the infanticides, which were framed as the outcome of Anna's nefarious intention.

If we compare the two cases, Matteuccia's records present several situations in which she provided help and healing, revealing the client's private reasons for requesting help - e.g. domestic abuse, failing marriages, sickness in the family caused by jealousy. Perhaps Matteuccia disclosed private information to disprove the maleficium charges. In Anna's records, the only instances which can be seen as healing or helping are her confessions of the use of protection charms, and the only piece of private information is the one extracted regarding Winder's daughter and Fauhtin's daughter. Possibly the two interrogations unfolded in different ways and allowed for different kinds of evidence. The trials might also have been recorded in different manners. In the absence of other clues, it is impossible to differentiate between what the prosecution knew and used during questioning and what was disclosed 'intentionally' by

41 Ibidem, fol. 5 or. 
the defendant as evidence of her innocence. ${ }^{42}$ However, it seems reasonable to conclude that for Matteuccia it could have been useful to admit to practices that might be considered helpful, whereas for Anna acknowledging other activities as a midwife could provide an opportunity for others to come forward and add more charges. Thus, information appears to be a significant bargaining tool, which could be withheld or released according to the healers' inclination, their understanding of the risks, and their evaluation of the situation during trial.

Although the fate of the women requesting abortions from Anna is unknown, witch trials almost always had a ripple effect. In this case, the consequences were felt after Anna's demise as her son was also executed under accusations of aiding Anna in committing infanticide. Although Anna implicated other members of the community as having taken part in the sabbath, this appears to have been taken only as background information for the primary focus of the trial - Anna's practices as a midwife. This is probably a manifestation of contemporary anxieties surrounding abortion and infanticide at a time when many children belonging to different age groups were apparently dying. ${ }^{43}$ The cultural and natural circumstances, such as epidemic outbreaks that coincide with accusations of witchcraft, also need to be taken into account in order to understand why a given trial was taking place. ${ }^{44}$ Such impactful events provide a context for how the accused would respond to interrogations and decide to withhold or release information about fellow villagers.

The cases of Matteuccia and Anna Starck reveal how specific circumstances and social dynamics at the village level crucially shaped the occurrence of trials. As pointed out by Walter Rummel, ${ }^{45}$ local healers were not a frequent target of the witch hunts as their persecution depended on fellow villagers denouncing them to the authorities. Since they played an important role in their communities and were therefore usually deemed worthy of protection, a significant disruption in local social dynamics had to occur before a person took recourse to the authorities against the healers. The reasons for such disruption are not

42 This is particularly evident in the records of Anna's trial which consist of a list of her answers without the corresponding list of questions. Thus, even though there are many questions to which Anna responds negatively, we do not know exactly what she is denying.

43 Lindemann M., Medicine and Society in Early Modern Europe (Cambridge - New York: 2010) 34 .

44 See Briggs R., "Witchcraft and the Local Communities: The Rhine-Moselle Region", in Levack B. (ed.), The Oxford Handbook of Witchcraft in Early Modern Europe and Colonial America (Oxford: 2013) 199-217, here 200.

45 Rummel, “'Weise' Frauen und 'weise' Männer” 359. 
always explicitly mentioned in the trial records, but in the cases presented here, we may suspect that Matteuccia's broad clientele and her meddling with private relationships as much as Anna's presence at the deaths of many children could have sparked tension. In such instances, the trials usually caused further disruption through either the release of private information or the implication of other local figures in ostensibly demonic activities, generating suspicion, gossip, and often triggering chain trials involving several members of the community. Modes of confidentiality were, therefore, not only the ways by which healers retained private information, but also a vital part of these local dynamics in which different members of the community attempted to control the circulation of certain types of information. From the services that certain healers were able to provide, the gossip surrounding a person's visit to the healer, or simply the trivial details of everyday life, people always had to negotiate or conceal information to maintain harmonious collective interactions.

\subsection{Negotiating Information}

Healers were aware of the consequences of the exposure of secrets within the community. One case that particularly highlights the awareness of such consequences is the trial against Clara Hoffmann (1631-1654). In 1654 Dommershausen, part of the Catholic Electorate of Trier, a certain Johannes Firen's young daughter fell seriously ill. He searched for different forms of help and was convinced that she was bewitched. He then sought a local 'Wahrsager' ('soothsayer') and asked him to identify the person who had cast a spell on his daughter. The soothsayer did not want to perform such a service, but Firen insisted. ${ }^{46}$ 'Nit bewilligen wollen' ('reluctantly'), the practitioner agreed to do something that would affect the guilty person's arm so that Firen would be able to identify the one responsible for his daughter's illness. In the following days, Clara Hoffmann appeared with a lame arm. Firen then went to court and accused her of witchcraft.

Together with Firen's accusations, several witnesses testified to her character, some of whom also accused her of witch-like actions. The local practitioner who allegedly affected her arm was not presented as suspicious, and his practices were not denounced as witchcraft. Nevertheless, the soothsayer sought by Firen was probably aware of the risk involved in performing this kind of

46 Landeshauptarchiv Koblenz, Best. 33, Nr. 8619, fol. 2. 
activity, hence his initial hesitation. ${ }^{47}$ This case reveals that the relationship between healers and their clientele was not a mercantile one in which service was only rendered in response to demand and in exchange for monetary compensation. Rather, it was something much more personal and less straightforward, allowing for negotiations of boundaries on both sides.

The healer appears to have had a certain responsibility within the community, and compromises were often reached between specialists and the people who sought them. There are several instances in which healers are reported to have appeared in trial to support - most times unhesitatingly - people who were accusing others of witchcraft. ${ }^{48}$ Even Anna Starck knew a charm to protect against witchcraft, and witch detection was a common part of the repertoire of local practitioners. ${ }^{49}$ In these particular cases, the testimony of the healer in trial was not a breach of the bonds between practitioners and their clientele but rather a reaffirmation of those bonds before the court. The healers' expertise in preventing the effects of witchcraft and identifying or banning witches could be instrumentalised in trial either as evidence to denounce somebody else as a witch (as in the case of Clara Hoffmann) or as proof of their own meddling with demonic agents (as in the case of Anna Starck).

The liminal position of the local healer - as a useful member of the community, but also as a performer of unsanctioned practices - allowed the formation of different bonds. Even though healers enjoyed a relative position of power by safeguarding private information and specialised knowledge required by the community, many of their practices existed in an ambiguous space between the accepted and the condemnable, which could give other members of the community (such as Firen) a certain leverage when negotiating services. As such, these bonds are more than just benign agreements that harmonise the collective experiences in society. Modes of confidentiality do not only constitute a system aimed at the protection of the participants involved, but they also function as a crucial component in negotiations of power in which private information could double as a means of trading. The trading of secrets

47 This case was also presented by Rummel in order to show how healers were not a category consistently victimised by witch trials. However, it is important to stress that such practices were mostly not sanctioned by religious or secular authorities, so appearing in court and admitting to the use of such rituals could have serious consequences depending on the circumstances of the trial.

48 See Walz R., Hexenglaube und magische Kommunikation im Dorf der Frühen Neuzeit: die Verfolgungen in der Grafschaft Lippe (Paderborn: 1993) 217.

49 In the German context, specialists in identifying and protecting against witches were usually called Hexenbanner. See Ruff M., Zauberpraktiken als Lebenshilfe:Magie im Alltag vom Mittelalter bis Heute (Frankfurt: 2003). 
might seem self-evident when we talk about the political dealings of the elites, but ordinary people could also find ways of using information as part of their survival strategies. When their position within the community was at stake, people accused of witchcraft, healers, and people desperate for solutions to their problems had to make use of the tools available, which in many cases would be the secrets - real or created - of others.

\section{3}

\section{Conclusion}

In order to understand the examples given above as cases illustrating modes of confidentiality between local healers and their patients, it is important to deconstruct the notion of confidentiality as a right that is given. Confidentiality has to be seen as something which is created, shaped, and dismantled on the basis of individual circumstances and within particular relationships. Each of the cases discussed here entails different forms of relationship at play in accusations of witchcraft and shows how these circumstances would result in the upkeeping or dissolution of different modes of confidentiality in trial.

Local healers were privy to detailed information about the health and daily issues of the members of their community. Some of this information could be revealed in a trial in order to disprove charges and to portray their practices as a service to the community. At the same time, this private knowledge could also be instrumentalised as evidence against them in court. Given the services healers provided and how they operated in the interstitial space between permissible and condemnable behaviour, most people would only feel safe to visit them if some form of trust was established - usually through these unspoken modes of confidentiality between healer and patient. However, these modes of confidentiality were crucially dependent on village dynamics.

In addition to establishing ways in which information circulated between healers, patients, and their surroundings, modes of confidentiality were part of the strategies that simultaneously secured the social life of the village and allowed for negotiations of power. Whereas the safety of people in everyday life depended upon the maintenance of these bonds, in the case of a trial, it might have been safer for such bonds to be broken.

If we wish to study confidentiality as an historical practice rather than regulated rights, it is crucial to avoid the pitfall of applying the concept of confidentiality to historical sources in an anachronistic manner. People tend to try to establish boundaries to regulate external access to their persons and their secrets, but the strategies for doing so are not the same across time and social conditions. Witch trials, in particular, show the ways in which power relations 
play a defining role in how private information was kept, revealed, or instrumentalised in the early modern period. Thinking about how ordinary people from the past communicated and negotiated information is vital if we wish to understand how our current definitions and legal practices of privacy and confidentiality came into existence on the backbone of historical experiences.

\section{Bibliography}

Bailey M.D., "Nocturnal Journeys and Ritual Dances in Bernardino of Siena", Magic, Ritual, and Witchcraft 8.1 (2013) 4-17.

Behringer W., Witchcraft Persecutions in Bavaria: Popular Magic, Religious Zealotry and Reason of State in Early Modern Europe (Cambridge - New York: 2003).

Briggs R., The Witches of Lorraine (Oxford: 2007).

Conti F., "Notes on the Nature of Beliefs in Witchcraft: Folklore and Classical Culture in Fifteenth Century Mendicant Traditions", Religions 10.10 (2019). Online edition [https://www.mdpi.com/2077-1444/10/10/576].

Cossar R., Clerical Households in Late Medieval Italy (Cambridge: 2017).

Dean T. - Lowe K.J.P., Marriage in Italy, 1300-1650 (Cambridge: 1998).

De Blécourt W., "Witch Doctors, Soothsayers and Priests. On Cunning Folk in European Historiography and Tradition", Social History $19 \cdot 3$ (1994) 285-303.

Ernst W., Beschwörungen und Segen: angewandte Psychotherapie im Mittelalter (Cologne: 2011).

Ferguson A., "The Lasting Legacy of a Bigamous Duchess: The Benchmark Precedent for Medical Confidentiality", Social History of Medicine 19.1 (2006) 37-53.

Frider P., Consultationum Saxonicarum (Frankfurt, Nicolai Hoffmann: 1616).

Ginzburg C., "The Inquisitor as Anthropologist", in Clues, Myths, and the Historical Method (Baltimore, MD: 1992).

Ginzburg C., Ecstasies: Deciphering the Witches' Sabbath (New York: 1991).

Harley D., "Historians as Demonologists: The Myth of the Midwife-witch", The Social History of Medicine 3.1 (1990) 1-26.

Holzmann V., "Ich beswer dich wurm und wyrmin ..." Formen und Typen altdeutscher Zaubersprüche und Segen (Bern - Berlin - New York: 2001).

Hutton R., "The Wild Hunt and the Witches' Sabbath", Folklore 125.2 (2014) 161-178.

Levack B. (ed.), The Oxford Handbook of Witchcraft in EarlyModern Europe and Colonial America (Oxford: 2013).

Lewis M.B., Infanticide and Abortion in Early Modern Germany (London - New York: 2016).

Lippi D. - Weber D., "Witchcraft, Medicine and Society in Early Modern Europe", Archives of the History and Philosophy of Medicine 75.1 (2012) 68-73. 
Maehle A.-H., "Protecting Patient Privacy or Serving Public Interests? Challenges to Medical Confidentiality in Imperial Germany", Social History of Medicine 16.3 (2003). Mammoli D. (trans.), Processo alla strega Matteuccia di Francesco, 20 marzo 1428 (Todi: 1969).

Midelfort E., Witch Hunting in Southwestern Germany (1562-1684) (Stanford, CA: 1972).

Montesano M., Classical Culture and Witchcraft in Medieval and Renaissance Italy (Cham: 2018).

Pavlac B., Witch Hunts in the Western World: Persecution and Punishment from the Inquisition through the Salem Trials (Westport, CO - London: 2009).

Roper L., "Witchcraft and the Western Imagination", Transactions of the Royal Historical Society 16 (2006) 117-141.

Ruff M., Zauberpraktiken als Lebenshilfe: Magie im Alltag vom Mittelalter bis Heute (Frankfurt: 2003).

Rummel W., “Weise' Frauen und 'weise’ Männer im Kampf gegen Hexerei: Die Widerlegung einer modernen Fabel”, in Dipper C. - Klinkhammer L. - Nutzenadel A. (eds.), Europäische Sozialgeschichte. Festschrift für Wolfgang Schieder (Berlin: 2000) $353-375$.

Schulz M., Beschwörungen im Mittelalter: Einführung und Überblick (Heidelberg: 2003).

Stolberg M., "Learning from the Common Folks. Academic Physicians and Medical Lay Culture in the Sixteenth Century", Social History of Medicine 27.4 (2014) 649-667.

Stolberg M., “'You Have No Good Blood in Your Body'. Oral Communication in Sixteenth-Century Physicians' Medical Practice", Medical History 59.1 (2015) 63-82.

Walz R., Hexenglaube und magische Kommunikation im Dorf der Frühen Neuzeit: die Verfolgungen in der Grafschaft Lippe (Paderborn: 1993).

Weindling P. (ed.), Healthcare in Private and Public from the Early Modern Period to 2000 (New York: 2015).

Whaley L., Women and the Practice of Medical Care in Early Modern Europe, 1400-1800 (London: 2011). 